\title{
Psychological Factors, Influencing the National Political Culture within a Multi-Ethnic Society, Role of Socialization and Globalization for the Multinational State Political Culture Development
}

\section{Lyazzat Ilimkhanova}

PhD doctoral candidate, Independent Scientist - researcher,

Email:lyazzat.ilimkhanova@gmail.com

\section{Mukhan Perlenbetov}

Doctor of Psychological Sciences; professor and vice-rector of Kainar University; academician of the Kazakh National Academy of Sciences. Email:phd2014.kz@gmail.com

Tursynbek Baimoldayev

Dr of Pedagogy, professor of KazNPU after Abai

Zhanatbek Ishpekbayev

Candidate of Political Sciences KazNPU after Abai. Email:phd2014.kz@gmail.com

Mergenbai Kurganbekov

KazNPU after Abai, phd2014.kz@gmail.com

Saltanat Tazhbayeva

Candidate of Pedagogical Scienses KazNPU after Abai. Email:phd2014.kz@gmail.com

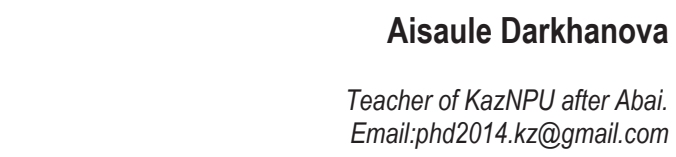

Galiya Bilyalova

Dr. of Philosophy, Kazakh-British Technical University, docent. Email: gbilyalova@yandex.kz

\section{Zhibek Bimaganbetova}

Docent, Candidate of philological science, chair of diplomatic translation, International Relations faculty. Email: phd2014.kz@gmail.com 


\section{Abstract}

This article contains a psychological analysis of the national political culture factors within a multinational state. On this basis, the psychological aspect of social relationship among the representatives of different ethnicities is reflected. The impact of ethnos on the political culture is shown. The main values and determinants of political culture are described; the analysis of the political socialization is reflected; its main types are presented. Also, the national issue within a multinational state is analyzed. The globalization process analysis is performed and its role and impact on the multinational state is reflected.

Keywords: factor, ethnos, ethnicity, ethnic affiliation, culture, social environment, behavior, relationship psychology, determinants, value, socialization, globalization.

\section{Introduction}

While studying the society political life, Spencer (English sociologist) claimed that people and their development level at average determine the policy set up by them. The rule of the people means not only the ability to conduct national public life, but also the ability to rule the state. The successful government requires that the nation (or separate individual) show responsibility for everything happening within the society.

The state and its people are connected to each other by three essential principles. These are knowledge, law and order. Adherence to these principles guarantees the political rule of state, independence and freedom of the individual. Political culture results from the degree of the state citizens' involvement into the political process of their state, as well as their impact on the political processes. Political culture main trends refer to the spiritual, ideological, educational and instructional areas of the state or political parties and movements, as well as of church. Political culture is set up under the influence of mass media, business, science, family, educational institutions, staff, etc.

All these factors determining the political culture are of a great importance within the multinational society. The state and whole world stability and prosperity directly depend on the competence degree applied while developing the political culture.

\section{Research}

Before becoming aware of the psychological factors influencing the national political culture one should understand what is political culture.

The political culture may be defined as part of the general culture, including historical experience, as well as awareness of the political and social events, values, qualifications and trends influencing the society political behavior. Besides, the political culture represents a system of political behavior norms set up within the society, its vision of politics, methods of different events, political terms and symbols evaluation and analysis. Development of the political power and political culture takes place simultaneously. Improvement of the political power relationship leads to the political culture development, thus making up the world perception within the society, evaluating the political power and setting up certain patterns, assertions and cultural knowledge, which allow determining every individual way of life.

Political culture reflects the nation historical evaluation of its past and sets up its aims for the future. Also, it makes up the perception of other political systems. Any political entity (individual or nation, group, political movement or organization) may become the political culture bearer and support.

Every nation or ethnos has its national political culture made up of different factors. The nation political culture has certain national characteristics, of which the most important are the nation thought pattern and its national character. These characteristics result from customs, traditions, behavior patterns, regulating the relationship among people in the course of many generations history. The thought pattern is represented by the nation, nationality or ethnic group general intellectual, mental, cultural and emotional specific features, relevant for a certain individual as well. The thought pattern yields a certain individual view of world and way of thinking. Every ethnic affiliation is characterized by its own thought pattern resulting from its historical, social, economic and cultural development. This thought pattern includes the morality and behavior norms, religious affiliation, reality awareness and evaluation, and other specific features. A person thought pattern is strongly expressed in case this person becomes part of another cultural and political environment.

The national character is represented by persistent psychological attributes specific of the most part of the nation representatives, these attributes making the nation different from other ethnical groups. The nation specific features may be persistent, temporary, as well as native-grown or borrowed. These features become the determinant factors of difference between nations. 


\section{History of the Political Culture Emergence}

Political culture development resulted from the political relationship emergence. This term was applied for the first time by the German philosopher of the XVII century Johann Gerdner; however this term was coined in the political science not earlier than in the 50-60s of the XX century by the American G. Almond. This political analyst noticed that countries that got rid of the colonial regime tried to copy the system of American political institutions to change in essence the political situation in their countries; however, all these innovations failed. While clearing up this failure reasons, the political culture concept was set up.

\section{4. "Political Culture" Concept}

Political culture comprises both the political awareness and behavior. The "political culture" concept covers certain aspects of the political behavior and awareness. This concept reflects the political patterns referring to the existent political systems, as well as the ideas about an ideal political system and its functioning aimed at bringing maximum benefit to the society. The "political culture" concept consists of logical and reasonable behavioral factors, including the affective and unconscious aspects, such as emotional expressions and temperament adherent to a certain social medium.

\section{Types of Political Culture}

The American political analysts G. Almond and S. Verba, authors of book "Civil Culture" published in 1963, distinguished three main types of political culture, namely: a) patriarchal; 2) subject type; 3) participative type.

The patriarchal (parochial, traditional) type of political culture is characteristic of politically undeveloped societies, of whici the citizens don't participate in their state political life. People are totally indifferent to any political decisions made by the central power and other political institutions, while their interest in the political life is limited to local events only. This political culture type refers to the lack of knowledge of politics. The power is held by chiefs, mystery men, while people take interest in settling economic and religious matters only.

The subject type political culture is characterized by the political inactivity and distance of citizens from the politics area; however they are aware of the political institutions activity, they may orient themselves in politics and evaluate the authorities' actions, while their interest is limited to obtaining practical effects from power-holders. This political culture type is characteristic of the feudal system, authoritarian and totalitarian regimes. In such conditions people resign themselves to authorities control for fear of diverse repressive methods or in the hope of further prosperity as a result of a complete obedience.

Participative political culture type is incident to a progressive society characterized by a differentiated and developed political system. In this case people take an active part in the political life; they show interest and are able to influence the political process of both their own country and the whole world. They are able to give a certain direction to the political process by legal means, being guided by the human values. This political culture type is characterized by freedom of speech and tolerance.

These political culture types are inexistent in their pure forms. As a rule, the political culture shows mixed characteristics, and it is called the civic consciousness culture.

In the context of the democratic society evolvement, a new political culture type may be set up represented by a synthesis of the historical experience for completely new political relationship development. The core of the political culture is represented by the society humanistic ideas and its morality. These values have a great impact on the political culture setting up and development. At the same time the society democratization is a real basis for these values implementation in real life.

\section{Ethnicity and Political Culture}

In the course of ethnical processes, ethnos is subject to such changes as consolidation and assimilation. Aspiring to a sustainable existence, the ethnos set up its own social and territorial units, states, which evolved forming political cultures incident to that specific ethnical society.

The main characteristics of ethnos are:

a) General awareness of the territorial integrity, historical origin, general culture and wealth. As a rule, they speak one language; 
b) National identity or politically shaped awareness of the state and native land;

c) The ethnical group members awareness of their community and this specific group affiliation.

The representatives of one and the same ethnos are often characterized by a common physical image, religion, geographic position, language and economic specialization. They may also be distinguished by specific clothing and cuisine.

\section{Factors Influencing the Political Culture Evolvement}

Countries having adopted a common social and political system may be completely different in terms of cultural and political relationship. This difference may result from such factors as the country geopolitical position, historical development processes, and economic factors peculiarities. The ethnic affiliation and national particular aspects also have an impact on different nations' political culture. The result of these ethnic peculiarities is the impossibility of a unique political culture adoption. Thus, countries with colonial, totalitarian and authoritarian regimes could not create the state political pattern based on either the American or European model.

\section{Political Culture Value}

The main value of this concept consists in the fact that political culture reflects the most important reasons of individuals' and social communities' political behavior in real existence conditions. Behavior is one of the culture development methods. Behavior in political culture determines the attitude of an individual towards authorities in power and vice versa. While examining the political behavior of the politics subjects, one should consider the specific character of their political culture. To get a complete idea of the politics subject, one should possess enough information on his political behavior, this information being consequently subject to analytical processing and analysis. In this way, one may obtain a complete description of a specific subject political culture evolvement.

\section{Psychology of Relationship within the Political Culture}

The psychology division specialized in the area of the relationship psychology within the political culture is called political psychology. It studies the individual political behavior in connection with foreign (wars, terrorist acts, ethnical conflicts, political decisions) and domestic (participation in the political life of the country, political preferences evolvement, struggle for abolishment of minorities discrimination, etc.) policies. The political psychology area applies methods referring to the political subject individual behavior analysis.

The tasks of political psychology consist in:

- Setting up the psychological basis of a successful political leader activity (behavior model);

- Up-building the election campaign;

- Defining the types of political communication between general population and the leader;

- The leader successful image cultivation ;

- Settling issues referring to political conflicts.

\section{National psychology}

The national and ethnic psychology - is a complex two-level entity, consisting of two factors, one of which is the unreasonable national behavior, and the other one - the reasonable national awareness. Namely these factors are the basis of different nations' mental and psychological make-up.

\section{Political Culture Determinants}

The political culture setting up and adjustment are influenced by internal and external factors. As stated above, the external factors are: 1) political society (state) environment and the impact on it of social, economic, political and cultural system of the neighboring states; 2) historical events, influencing the respective political community; 3) civilization processes general development; 4) contemporary social and economic development; 5) institutional conditions. Internal factors influencing the political culture development are represented by the following categories: a) social and psychological; b) group; c) individual and psychological. 


\section{Group Determinant Analysis}

The social and psychological part of the determinant is characterized by a series of social and cultural phenomena, as well as the processes connected to them. These are the ethnical self-determination and self-assertion, tendency to regional isolation; expression of social (specific) behavior patterns; social identity crisis. Besides these factors, there are unconscious aspects of the social environment representatives' mentality, which predetermine its tendency to unconditional adoption of a certain power style and ideology, behavior patterns and mass scale attitudes, recognition of moral and value power authorities.

The group-type determinant includes social and demographic characteristics of social environment. These characteristics include: ethnic affiliation, gender, age, social, economic, educational and professional statuses.

Individual and psychological part of the determinant reflecting the political culture peculiarities includes motivational and conceptual entities, personal characteristics and social identity specific features.

\section{Political Socialization}

To make sure the community political system functioning is favorable and integral, a continuous political culture development is needed; in this context, people should adopt political behavior patterns, as well as the political culture norms and values. This process is called political socialization. The political socialization main task is the person ability to orientate in the existent political system and perform functions assigned to the person by society. The person, who is unable to perform these tasks, will not be capable of defending his political and social interests.

Political socialization represents a complex process of the political system and individual interaction. The political system persistently influences the personality and transmits to it all priorities existent within the society, such as political behavior patterns, values and political directions adopted in this society. At the same time the political socialization assumes the individual personal efforts able to modify the political culture norms adopted by the society. The individual with personal earnest convictions may influence the political system by himself. Political socialization consists of 4 types dependent on nature of the person and political system interaction.

\section{Types of Political Socialization}

- Harmonic type - is characterized by a reasonable relationship between the political system and the individual. This type reflects a psychologically positive relationship between government agencies and the individual, assuming the existence of a homogeneous cultural environment, civic society and long-standing democratic traditions;

- Pluralistic type - indirect interaction between the political system and individual. It assumes the existence of many different subcultures, including the political ones. The political socialization of the individual takes place within one of the existent subcultures. However, the great variety of social groups creates the possibility of a consensus achievement, as all participants in the political process recognize the liberal and democratic values adherent to the political system;

- Conflictive type - this type is based on opposition and inter-group struggle. Communities referring to the conflictive socialization type are characterized by a high level of political violence and hard struggle among bearers of diverse subcultures.

- Hegemonistic type - is characterized by an extremely negative attitude of the individual to any political and social system. Representatives of this type recognize their own political system only. Evolvement of an individual political culture is based on values adherent to a certain political ideology, social group, and religious community. This type of political socialization is characteristic of closed political systems recognizing their own political directions and values only.

\section{Political Socialization in a Multinational State}

Inter-ethnic relations are the main integral part of political relations within a multinational state. The state should settle and regulate relations among all ethnic and national groups residing in its territory. The national policy is set up on the basis of norms, rules and principles by which the national relations are managed. Each country has its own national policy; however, there are methods and ways, historically tested, that may be applied for an optimal settlement of the 
national issue. The main political aspects on the inter-ethnic relations system are: national self-assertion, equality of nations, protection of national and international interests, creating conditions for the national culture and languages favorable development, as well as promotion of the domestic labor force interests in authorities' structures. The national idea is set up proceeding from the political culture, political behavior, and provisions, being also influenced by traditions, geographical, cultural and residential conditions, and social attitudes. Any questions referring to the inter-ethnic relations are settled by political means.

The national issue refers not only to the national opposition and discord yielded by the national inequality and oppression; this is a major social and political problem that should be settled by the state with a high cultural level and developed economy. The national issue in a multinational state is settled on the basis of the following democratic principles:

1) Right of nation to self-assertion;

2) Autonomy;

3) Equality of rights for all ethnic groups residing on the same territory;

4) Personal right priority.

To settle the national issue, legal forms are adopted at the state-level. Within a unitary state these forms refer to the setting up of autonomous units, setting up of a federal state.To appreciate the efforts required to support the unique political culture development in Russia, the ethnic composition of our state shall be studied, taking into account that Russia is the world most multi-ethnic country.

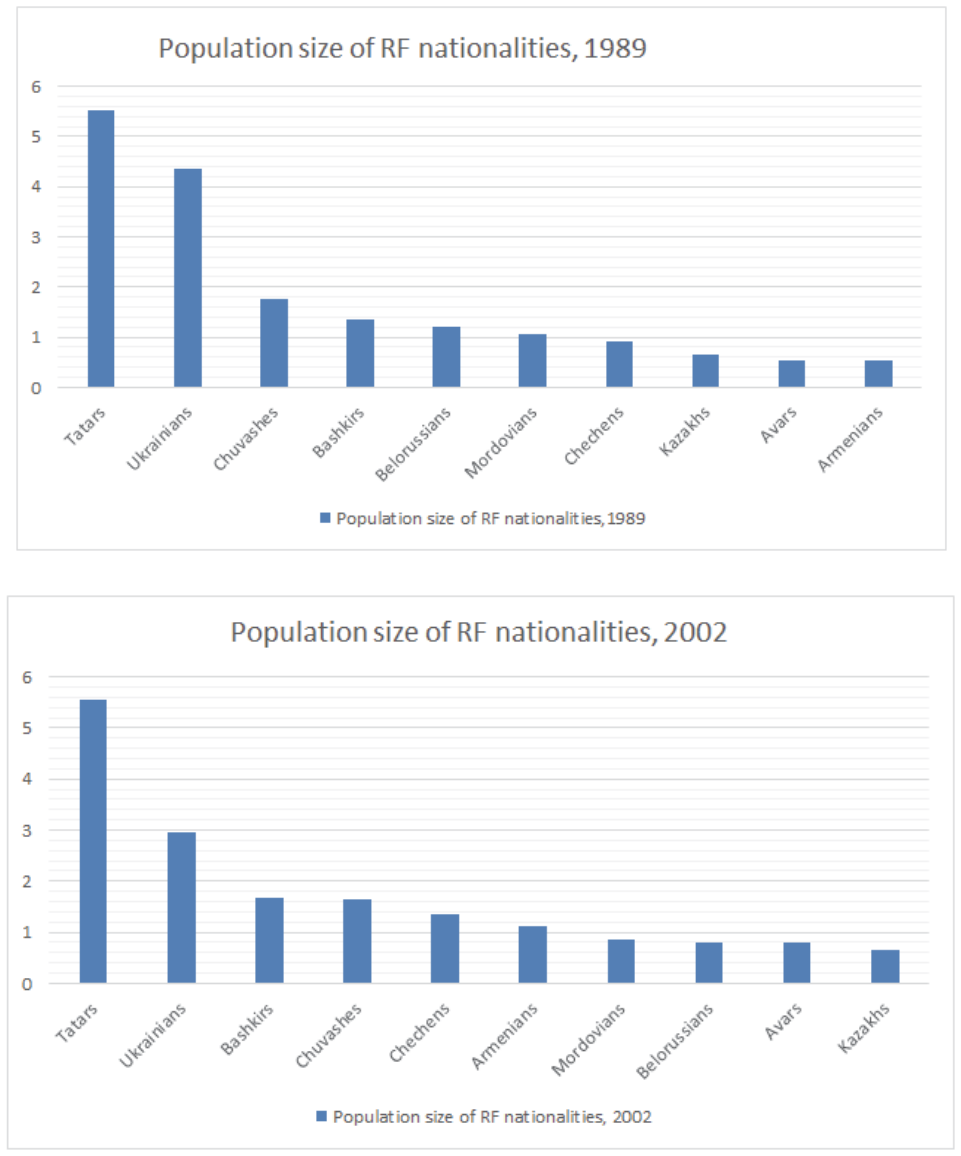




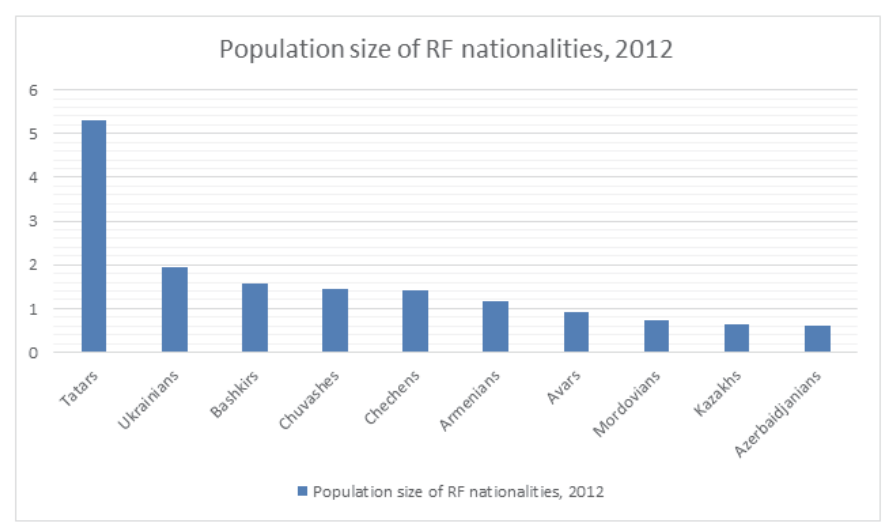

Data provided by the federal press center"Census-2010"(http://www.centerasia.ru/issue/2012/29/4311-samiemnogochislennie-nacionalnosti-v.html).

\section{Globalization and Its Importance within a Multinational State}

Globalization - is a world political, economic and cultural process of integration and unification. This is the result of different legally recognized market systems evolution. Globalization is an important factor determining a fall in the national identification of states. The main reasons of globalization are: transition of the industrialized society to the informational one; decentralization of the centralized economy; integration of the national economy into the world economy system; implementation of new informational technologies. The globalization process intensifies the states and nations mutual interference and interdependence. This process is characterized by certain directions, such as:

- General expansion of transnational corporations activity;

- Migration process globalization; financial markets globalization;

- International economic integration within separate regions;

- Founding of diverse international organizations operating in the financial and economic areas.

The globalization process brings a series of advantages. These are:

- Economy growth enhancement, that is most goods are produced in regions with a cheap labor force, thus ensuring:

a) More favorable terms for the goods trading;

b) Considerable decrease of production costs;

c) Profit growth;

d) Increase of possibilities for production development;

e) A more efficient process development;

f) More opportunities for countries not involved in the scientific research area to apply the results of scientific achievements.

- Rapprochement between countries;

- Social and cultural unification among people;

- Prevention of states participation in extreme political actions and their interests' promotion.

Disadvantages of globalization are:

- Imposing a unique consumer standard;

- Decrease of domestic production as a result of the obstacles created;

- Lack of any consideration of different countries cultural, historical and economic peculiarities;

- Imposing a life pattern that is unacceptable for countries with traditional life patterns and confession;

- Nationalism explosion in under-developed countries as a result of the developed states tendency to the world leadership;

- Loss of national cultures specific features.

A multinational state is characterized by the priority of the nations' right to self-assertion over the state territorial integrity principle, this resulting in the separatism and extremism phenomena. Consequently, to settle global problems, 
serious and reasonable decisions should be taken and general efforts of humanity as a whole should be made.

\section{Analysis of the National Political Culture Development within the Globalization Process}

Within a multinational society, the political culture change is influenced by the following endogenous factors: national history, religion, traditions, mental behavior of ethnic groups and the general globalization process.

The globalization factor enhances the cross-border processes of individuals and organizations interaction, these processes being no longer initiated by national governments. As mentioned above, the interconnection and interdependence between countries and regions resulting from the enhancement of mutual relations between national territories registered a several-times increase; that is why national and regional political institutions are responsible for the settlement of both local problems and essential issues referring to the humanity survival.

\section{Globalization Factors Influencing the International Policy of States}

At present, global processes represent the key-factors of international policy; however globalization is not the single driving force in international political and economic processes. It is not oriented at homogenization of the social and economic environment and it is not the solution for economic, political, cultural and social problems experienced by certain countries and regions. Certain political analysts noticed that the globalization processes have an unbalanced impact over the political reality. Referring to the political culture area, which is directly connected to politics, globalization enhances problems yielded by the national political culture. Despite one of the globalization concepts - "considering our land as being the unique space and decreasing the significance of geographical barriers", globalization cannot satisfy the sovereign states requirements and remove their cultural differences.

\section{Globalization Consequences}

Consequently to an intensified intervention of international organizations, developed states, separate political leaders, as well as diverse transnational, multinational and mega-corporations into the political life of national and multinational states, the political culture turns into a provincial and secondary one.

Global processes create a new environment (informational, technological, social, cultural and economic), unify people's was of life, and contribute to the unified social behavior models creation. On the other hand, globalization enhances the society and separate individual civilization and cultural development problems. Political, economic and social consequences of global processes, unifying the political and management practices represent a serious danger for political cultures, institutions and traditions. There should be mentioned that the globalism positive influence, meaning the totalitarian culture disappearance, is still present in Cuba and Democratic People's Republic of Korea. Multinational states face the problem of adjustment to norms imposed by global, post-sovereign political culture.

\section{Summary \& Conclusions}

Proceeding from the facts mentioned above, there may be concluded that despite the globalization processes, the multinational society, characterized by a developed political culture, may decrease the globalization risks and stop the inter-ethnic local conflicts on its territory.

Within a multinational state, it is important to carefully consider both the national issue and the globalization process. The economic policy and the national issue are interdependent, while the inter-ethnic conflicts are influenced by the economic situation of the respective country. It is important that, within the multinational state, the political culture development is enhanced by means of various psychological factors. The state shall tend to increase the educational level of its citizens, increase welfare, and apply psychological, economic and political instruments to ensure a life worth living for the citizens, their free will expression, security, and productive work.

The Western civilization and culture are characterized by a developed civil society with a fully formed political culture; at the same time, in many multinational states, this process is under evolvement, and it has its specific features and peculiarities. Nevertheless, this process is under way in the whole world.

\section{Acknowledgements}

Gozman and Shestopal working in this area earned an honorific mention for the discovery of the political culture direction. 


\section{References}

Amelin V.V. Problems of Inter-Ethnic Conflicts Settlement.

Golovin N.A. Theoretical and Methodological Basis of the Political Socialization Research.Saint-Petersburg. 2004.

Gozman L.I., Shestopal E.B. Political Psychology. Rostov on Don, 1996.

Golosov G.V. Comparative Politology. MSU, 1995.

Eliseev S.M. Political Sociology. Study Guide. Saint-Petersburg, «Nestor-History» publishing house, 2007.

Irhin I.V., Zotov V.D., Zotova L.V. Politology: TextbookM.: Iurist,2002.

Course of lectures on «Politology»: module. (Guide).

NiconovVeaceslav. Globalization and State. (Thesis).

Olishanski D. Basis of Political Psychology. Textbook for HEl.

Political Psychology. Textbook for HEl.Under the general editorship of A.Dercaci, V.Jucov, L.Laptev. 